\title{
INSIGHTS INTO THE RELATIONSHIPS OF PALEARCTIC AND NeARCtic lyMNAEIDS (MOllusCa: Gastropoda) BY RDNA ITS-2 SEQUENCING AND PHYLOGENY OF STAGNICOLINE INTERMEDIATE HOST SPECIES OF FASCIOLA HEPATICA
}

\author{
BARGUES M.D.*, HORÁK P.**, PATZNER R.A.***, POINTIER J.P.****, JACKIEWICZ M.******, \\ MEIER-BROOK C.******* \& MAS-COMA S.*
}

\section{Summary:}

Fascioliasis by Fasciola hepatica is the vector-borne disease presenting the widest latitudinal, longitudinal and altitudinal distribution known. F. hepatica shows a great adaptation power to new environmental conditions which is the consequence of its own capacities together with the adaptation and colonization abilities of its specific vector hosts, freshwater snails of the family Lymnaeidae. Several lymnaeid species only considered as secondary contributors to the liver fluke transmission have, however, played a very important role in the geographic expansion of this disease. Many of them belong to the so-called "stagnicoline" type group. Stagnicolines have, therefore, a very important applied interest in the Holarctic region, to which they are geographically restricted. The present knowledge on the genetics of stagnicolines and on their parasite-host

interrelationships is, however, far from being sufficient. The present paper analyses the relationships between Palaearctic and Nearctic stagnicoline species on the base of the new light furnished by the results obtained in nuclear rDNA ITS-2 sequencing and corresponding phylogenetic studies of the lymnaeid taxa Lymnaea (Stagnicola) occulta, L. (S.) palustris palustris (topotype specimens) and L. (S.) p. turricula from Europe. Natural infections with $F$. hepatica have been reported in all of them. Surprisingly, ITS-2 length and GC content of L. occulta were similar and perfectly fitted within the respective ranges known in North American stagnicolines. Nucleotide differences and genetic distances were higher between L. occulta and the other European stagnicolines than between L. occulta and the North American ones. The ITS-2 sequence of L. p. turricula from Poland differed from the other genotypes known from turricula in Europe. The phylogenetic trees using the maximum-parsimony, distance and maximum-likelihood methods confirmed (i) the inclusion of $L$. occulta in the branch of North American stagnicolines, (ii) the link between the North American stagnicolines-L. occulta group with Galba truncatula, and (iii) the location of the L. p. turricula genotype from Poland closer to L. P. palustris than to other European L. p. turricula genotypes. The Palaearctic species occulta is included in the genus Catascopia, together with the Nearctic species catascopium, emarginata and elodes. The results suggest a potential of transmission capacity for $C$. occulta higher than that of other European stagnicolines or Omphiscola glabra. The relatively low genetic distances between $\mathrm{C}$. occulta and $G$. truncatula and the clustering of both species in the same clade suggest that $C$. occulta may be potentially considered as the second lymnaeid intermediate host species of $F$. hepatica in importance in eastern and northern Europe, and probably also western and central Asia, after G. truncatula. L. p. turricula may be considered as a potential secondary vector of $F$. hepatica, at a level similar to that of L. p. palustris.

KEY WORDS : Holarctic stagnicolines, Lymnaea occulta, L. palustris turricula, rDNA ITS-2 sequences, phylogeny, Fasciola hepatica.
Résumé : Étude comparative de limnées (Mollusca: Gastropoda) PALÉARCTIQUeS ET NÉARCTIQUES PAR SÉQUENSAGE DE L'ITS-2 DE L'ADN RIBOSOMIAL ET PHYLOGÉNIE DES STAGNICOLINES HOTES INTERMÉDIAIRES DE FASCIOLA HEPATICA

La fasciolose à Fasciola hepatica est la distomatose présentant la plus large distribution aux plans longitudinal, latitudinal et de l'altitude. F. hepatica possède un grand pouvoir d'adaptation à de nouvelles conditions environnementales en raison de ses propres capacités et de celles de ses hôtes intermédiaires, des mollusques d'eau douce de la famille des Lymnaeidae, à coloniser le milieu. Plusieurs espèces de limnées considérées comme ayant un rôle secondaire dans la transmission de la distomatose hépatique ont cependant joué un rôle important dans l'extansion géographique de la maladie. Plusieurs appartiennent au groupe des stagnicolines. Celles-ci ont un intérêt pratique important en région holarctique où elles sont cantonnées. Les connaissances actuelles sur la génétique des stagnicolines et sur leurs relations avec le parasite dont elles sont les hôtes sont très limitées. Ce travail étudie les relations entre les espèces paléarctiques et néarctiques de stagicolines à la lumière des résultats du séquensage de l'ITS-2 de l'ADN ribosomial et de la phylogénie des taxa Lymnaea (Stagnicola) occulta, L. (S.) palustris palustris (specimens topotypes) et L. (S.) p. turricula d'Europe. Une infestation naturelle par $F$. hepatica a été rapportée chez chacune d'entre elles. Fait surprenant, la longueur de I'ITS-2 et la teneur en GC de L. occulta sont les mêmes et parfaitement ajustés avec ceux des stagnicolines nord-américaines. Les différences sont plus importantes entre L. occulta et les autres stagnicolines européennes qu'entre L. occulta et stagnicolines nord-américaines. Le séquensage de l'ITS-2 de L. p. turricula de Pologne diffère des autres génotypes connus de turricula d'Europe. Les arbres phylogénétiques obtenus par parcimonie, distances et maximum de vraissemblance confirment: i) l'inclusion de L. occulta à la branche des stagnicolines nord-américaines; ii) le lien entre le groupe stagnicolines nord-américainest. occulta et Galba truncatula; et iii) que le génotype de L. p. turricula de Pologne est plus proche de celvi de L. p. palustris que de des autres génotypes de L. p. turricula d'Europe. L'espèce paléarctique occulta est incluse dans le genre Catascopia, avec les espèces néarctiques catascopium, emarginata et elodes. Les résultats suggèrent une plus grande capacité potentielle de transmission de C. occulta que de celles des autres stagnicolines européennes et d'Omphiscola glabra. La petite différence génétique entre C. occulta et $G$. truncatula, ainsi que la proximité des deux espèces dans le même clade suggèrent que C. occulta pourrait, en importance, être considéré comme potentiellement la seconde espèce de Lymnaeidae hôte intermédiaire de F. hepatica, à un niveau équivalent de celui de L. p. palustris.

MOTS CLÉS : stagnicolines holartiques, Lymnaea occulta, L. palustris turricula séquences ITS-2 de I'ADN ribosomique, phylogénie, Fasciola hepatica. 


\section{INTRODUCTION}

F reshwater snails of the family Lymnaeidae are used as intermediate hosts by numerous digenean trematode species (mainly as first intermediate hosts, but also as second intermediate hosts as for instance in echinostomatids) (Erasmus, 1972; Brown, 1978). Many lymnaeid species are of applied interest because of transmitting several trematode species of large medical and veterinary impact, among which fasciolids (Mas-Coma \& Bargues, 1997), schistosomatids of birds and mammals whose cercariae they shed cause dermatitis or swimmer's itch in humans, and echinostomatids (see review in Bargues et al., 2001). Despite the applied interest of lymnaeid snails in epidemiological and control studies concerning the important trematode parasitic diseases they transmit, the present knowledge on the genetics of this gastropod group as well as on their parasite-host interrelationships is far from being sufficient. A good example of this situation is the systematic-taxonomic confusion in which this molluscan family is immersed (see review in Bargues et al., 2001). At lymnaeid species level, the problems are found mainly because of the interspecific morphological and anatomic uniformity numerous species show, usually giving serious difficulties in specimen classification, sometimes even impeding it (e.g. Oviedo et al., 1995). Moreover, intraspecific variation of shell shape is particularly well marked within lymnaeids depending on environmental conditions (Burch, 1968; Burch \& Lindsay, 1973), although a genetic component in shell shape has been shown at least in some lymnaeid populations (Samadi et al., 2000). In Europe, there are many specimen classification problems, mainly concerned with species of the "stagnicoline" and "radix" type groups (Glöer \& Meier-Brook, 1998). Recent papers suggested that nuclear ribosomal DNA (rDNA) and mitochondrial DNA (mtDNA) sequences

\footnotetext{
* Departamento de Parasitología, Facultad de Farmacia, Universidad de Valencia, Av. Vicent Andrés Estellés s/n, 46100 Burjassot, Valencia, Spain. *** Department of Parasitology, Charles University, Vinicná 7, CZ-128 44 Prague 2, Czech Republic.

**** Institute of Zoology, University of Salzburg, Hellbrunnerstrasse 34, A-5020 Salzburg, Austria

***** Laboratoire de Biologie Marine et Malacologie, École Pratique des Hautes Études, Centre de Biologie et d'Écologie Tropicale et Méditerranéenne, Université de Perpignan, UMR 5555 du CNRS, 52 , avenue de Villeneuve, 66860 Perpignan, France.

******* Department of Animal Taxonomy and Ecology, Adam Mickiewicz University, Szamarzwskiego 91A, 60-569 Poznan, Poland.

******** Forschungslaboratorien, Institut für Tropenmedizin, EberhardKarls-Universität Tübingen, Wilhelmstrasse 27, 72074 Tübingen, Germany.

Correspondence: Dr Maria Dolores Bargues, Departamento de Parasitologia, Facultad de Farmacia, Universidad de Valencia, Av. Vicent Andres Estelles s/n, 46100 Burjassot, Valencia, Spain.

Tel.: 34-96-354-42-98 - Fax: 34-96-354-47-69.

E-mail: M.D.Bargues@uv.es
}

were able to furnish appropriate markers to clarify the systematics of this snail group, as well as to establish lymnaeid species classification (Bargues \& Mas-Coma, 1997; Bargues et al., 1997; Remigio \& Blair, 1997a,b). Moreover, a very recent paper has already proved that the sequence of the second internal transcribed spacer (ITS-2) of the rDNA is a useful marker for resolving supraspecific, specific and population relationships in Lymnaeidae (Bargues et al., 2001). The results obtained showed up to which level the lymnaeid systematic confusion can reach. Several populations originally classified as belonging to different species showed identical ITS-2 sequences, and other populations originally classified as pertaining to the same species presented different ITS-2 sequences. Sometimes the sequence differences were very few, suggesting intraspecific variability (different genotypes). But sometimes differences detected among populations classified as pertaining to the same species were numerous, sufficient as to consider different species involved. Finally, the analysis of genetic distances and sequence differences found between the distinct populations and taxa studied allowed us to distinguish the upper limit to be expected within a single species and to how different twin species can be expected to be at rDNA ITS-2 sequence level.

The review of the European lymnaeids by means of ITS-2 sequence comparisons and corresponding maximum-parsimony, distance and maximum-likelihood analyses allowed us to distinguish many genotypes in a total of 11 species (one including two subspecies) distributed in four different genera (one comprising two subgenera) (Bargues et al., 2001): Lymnaea (Lymnaea) stagnalis (Linnaeus, 1758) (including four different genotypes); L. (Stagnicola) palustris palustris (Müller, 1774) (one genotype); L. (S.) palustris turricula (Held, 1836) (two genotypes); L. (S.) fuscus (Pfeiffer, 1821) (= S. vulnerata Küster, 1862) (four genotypes); L. (S.) corvus (Gmelin, 1791) (one genotype); Omphiscola glabra (Müller, 1774) (two genotypes); Radix auricularia (Linnaeus, 1758) (five genotypes); $R$. balthica (Linnaeus, 1758) $[=R$. peregra $($ Müller, 1774); = R. ovata (Draparnaud, 1805)] (three genotypes); $R$. labiata (Rossmaessler, 1835) $(=R$. peregra sensu Ehrmann, $1933 ;=R$. alpicola Westerlund, 1875) (two genotypes); $R$. lagotis (Schrank, 1803) (two genotypes); R. ampla (Hartmann, 1821) (one genotype); and Galba truncatula (Müller, 1774) (two genotypes). In agreement with the recent taxonomic review of Falkner et al. (2002), the taxa $R$. peregra and $R$. ovata enter in synonymies. Although used during decades, both taxa are very confusing because of the impossibility to know to which concrete species they actually refer. The resurrection of the taxa $R$. balthica, R. labiata and $R$. lagotis becomes thus clarifying. 
In this review paper of Bargues et al. (2001), two lymnaeid populations from Turkey were also included, appearing as populations 49 and 57 in Table I (see p. 90). The locality name at population 49 must imply identity of Bozdag and Söke. This is due to a regrettable error by one of the authors (C. Meier-Brook). After publication, the collector of the samples, Dr. Gerhard Falkner, drew his attention upon the fact that localities lie more than $100 \mathrm{~km}$ apart from each other. The collector had recognised the species difference as follows: $i$ ) in the Bozdag Mountains he collected the species then electrophoretically identified by C. MeierBrook (and also treated in Remigio \& Blair, 1997a, unfortunately also there under the erroneous locality name "Söke" instead of Bozdag) as Radix peregra sensu Ehrmann (now valid name $R$. labiata, according to Bargues et al., 2001); ii) the more southern population of Söke, however, had already been assigned, by Falkner, to a non-European species, which ressembles Radix natalensis (Krauss), a species otherwise reaching north to Egypt and Israel (the Söke lymnaeid was only classified as Radix sp., pending studies of Asian and African lymnaeids, by Bargues et al., 2001). Consequently, to users of the 2001 review paper it may be recommended to cross out, in the line of population 49, the locality names of "Söke, Aydin Sira Daglari" referring to the present paper.

Fascioliasis by $F$. bepatica is the vector-borne disease presenting the widest latitudinal, longitudinal and altitudinal distribution known. $F$. hepatica shows a great adaptation power to new environmental conditions which is the consequence of its own capacities together with the adaptation and colonization abilities of its specific vector hosts, freshwater snails of the family Lymnaeidae (Mas-Coma et al., 2003). Beside the very few lymnaeid species acting as preferential intermediate hosts, several other lymnaeid species only considered as secondary contributors to the liver fluke transmission have, however, played a very important role in the geographic expansion of this disease. Many of them belong to the so-called "stagnicoline" type group (MasComa et al., 2003). Stagnicolines have, therefore, a very important applied interest in the Holarctic region, to which they are geographically restricted. Thus, efforts to clarify this group are welcome, as the general confusion in stagnicolines does not only concern Europe, but also Asia and North America (see Hubendick, 1951).

The present paper has the purpose of analysing the relationships between Palaearctic and Nearctic stagnicoline species on the base of the new light furnished by the results obtained in rDNA sequencing and corresponding phylogenetic studies of the taxa $L$. (S.) occulta (Jackiewicz, 1959), L. (S.) palustris palustris and L. (S.) palustris turricula. Their parasitological interest lies in the fact that natural infections with the liver fluke
Fasciola hepatica (Trematoda: Fasciolidae) have been reported in populations of all of them. L. (S.) occulta is sequenced for the first time; the status of the two $L$. (S.) palustris subspecies could not be definitively established by the previous studies of the respective populations available so far (Bargues et al., 2001).

\section{MATERIALS AND METHODS}

\section{LYMNAEID MATERIALS}

S pecimens of the following lymnaeid populations have been newly sequenced: Lymnaea (S.) occulta from Gorzykowo (near the road connecting Wrzesnia and Brzezina), NW Poland; Lymnaea (S.) palustris palustris from Fure Sø, Denmark (topotype specimens, laboratory bred, legit G. Falkner); and Lymnaea (S.) palustris turricula from Siedzina (near Nysa in Lower Silesia), SW Poland.

The following rDNA ITS-2 sequences present in GenBank-EMBL were used: Lymnaea (Lymnaea) stagnalis genotype 1 (GT1) from Germany (Accession No. AJ319614), L. (L.) stagnalis GT2 and GT3 from France (AJ319615, AJ319616), L. (L.) stagnalis GT4 from Italy, France and Germany (AJ319617); Lymnaea (Stagnicola) palustris turricola GT1 and GT2 from Austria (AJ319618, AJ319619); L. (S.) palustris palustris from France, Germany and The Netherlands (AJ319620); L. (S.) fuscus GT1 from France (AJ319621), L. (S.) fuscus GT2 from Germany (AJ319622), L. (S.) fuscus GT3 from Austria and France (AJ319623), L. (S.) fuscus GT4 from Spain (AJ319624); L. (S.) corvus from Austria (AJ319625); Omphiscola glabra GT1 from Germany (AJ319626), O. glabra GT2 from France (AJ319627); Radix auricularia GT1 from Czech Republic, Austria and UK (AJ319628), R. auricularia GT2 from Czech Republic (AJ319629), R. auricularia GT3, GT4 and GT5 from France (AJ319630, AJ319631, AJ319632); $R$. balthica GT1 from France, The Netherlands, Spain and Iceland (AJ319633), R. balthica GT2 from France (AJ319634), $R$. balthica GT3 from France (AJ319635); R. labiata GT1 from Czech Republic and Turkey (AJ319636), R. labiata GT2 from Germany (AJ319637); R. lagotis GT1 from Czech Republic (AJ319638), R. lagotis GT2 from Austria (AJ319639); R. ampla from Austria (AJ319640); Radix sp. from Turkey (AJ319641); Galba truncatula GT1 from Spain, Portugal and Switzerland (AJ243017), G. truncatula GT2 from Spain, France, Portugal and The Netherlands (AJ296271); Hinkleyia catascopium (Say, 1817) from Wisconsin, USA (AJ319642) (Bargues et al., 2001), H. catascopium from Au Sable River, Michigan, USA (AF013143), H. elodes (Say, 1821) from Zeeb Road, Ann Arbor, Michigan, USA (AF013138), H. emarginata (Say, 1821) from Higgins Lake, Michigan, USA (AF013142), and H. caperata (Say, 1829) from south- 
western Manitoba, Canada (AF013139) (Remigio \& Blair 1997b). H. catascopium, H. elodes and H. emarginata were already considered conspecific by Remigio \& Blair (1997b) and, in agreement, H. catascopium was noted as the valid species, with $H$. elodes and $H$. emarginata as synonyms by Bargues et al. (2001); in spite of this, the latter two specific names will be used throughout in this paper to simplify reference to their corresponding ITS-2 sequences.

The rDNA ITS-2 sequences of three species of the family Planorbidae recently available in GenBankEMBL were also used for outgroup conformation: Biomphalaria pfeifferi (Krauss, 1848) (AY030361), B. amazonica Paraense, 1966 (AY030385), and Helisoma trivolvis (Say, 1817) (AY030403) (DeJong et al., 2001).

\section{MOLECUlar TECHNIQUeS}

\section{- DNA extraction}

Snail feet fixed in $70 \%$ ethanol and maintained at $4^{\circ} \mathrm{C}$ for several weeks were used for DNA extraction procedures. After dissection under a microscope, half of the foot was suspended in $400 \mu \mathrm{l}$ of lysis buffer $(10 \mathrm{mM}$ Tris-HCl, pH 8.0, $100 \mathrm{mM}$ EDTA, $100 \mathrm{mM} \mathrm{NaCl}, 1 \%$ sodium dodecyl sulfate SDS) containing $500 \mu \mathrm{g} / \mathrm{ml}$ Proteinase K (Promega, Madison, WI, USA) and digested for two hours at $55^{\circ} \mathrm{C}$ with alternate shaking each $15 \mathrm{~min}$. The procedure steps were performed according to methods outlined previously (Bargues \& MasComa, 1997; Bargues et al., 2001). Total DNA was isolated according to the phenol-chloroform extraction and ethanol precipitation method (Sambrook et al., 1989). The pellet was dried and resuspended in $30 \mu \mathrm{l}$ sterile TE buffer ( $\mathrm{pH} 8.0$ ). This suspension was stored at $-20^{\circ} \mathrm{C}$ until use.

\section{- rDNA sequence amplification}

The fragment corresponding to the ITS-2 of each lymnaeid was amplified by the Polymerase Chain Reaction (PCR) using 4-6 $\mathrm{ml}$ of lymnaeid genomic DNA for each $50 \mathrm{ml}$ PCR reaction, according to methods outlined previously (Almeyda-Artigas et al., 2000). The PCR amplification was performed using primers designed in conserved positions of 5.85 and $28 \mathrm{~S}$ rRNA genes of several eukaryote Metazoa species. The primers used were as described by Almeyda-Artigas et al. (2000). The primer LT1 (forward) 5'-TCGTCTGTGTGAGGGTCG (Bargues et al., 2001) was used for amplification and sequencing purposes. Amplifications were generated in a Peltier thermal cycler (MJ Research, Watertown, MA, USA), by 30 cycles of $30 \mathrm{sec}$ at $94^{\circ} \mathrm{C}$, $30 \mathrm{sec}$ at $50^{\circ} \mathrm{C}$ and one min at $72^{\circ} \mathrm{C}$, preceded by $30 \mathrm{sec}$ at $94^{\circ} \mathrm{C}$ and followed by seven min at $72^{\circ} \mathrm{C}$. Ten microliters of the reaction mixture were examined by $1 \%$ agarose gel electrophoresis, followed by ethidium bromide staining.
- Purification and quantification of PCR products Primers and nucleotides were removed from PCR products by purification on Wizard ${ }^{\mathrm{TM}}$ PCR Preps DNA Purification System (Promega, Madison, WI, USA) according to the manufacturer's protocol and resuspended in $50 \mu \mathrm{l}$ of $10 \mathrm{mM}$ TE buffer ( $\mathrm{pH}$ 7.6). The final DNA concentration was determined by measuring the absorbance at 260 and $280 \mathrm{~nm}$.

\section{- DNA sequencing}

The sequencing of the ITS- 2 of the rDNA was performed on both strands by the dideoxy chain-termination method (Sanger et al., 1977), and was carried out with the Taq dye-terminator chemistry kit for $\mathrm{ABI}$ 373A (Perkin Elmer, Foster City, CA, USA), using PCR primers.

\section{SOFTWARE PROGRAMS USED}

\section{- For sequence alignment}

Sequences were aligned using CLUSTAL-W version 1.8 (Thompson et al., 1994) and introducing sequences in different orders at random to reduce biases (Lake, 1991).

- For phylogenetic analysis

Maximum-parsimony, distance and maximum-likelihood methods were used in phylogeny reconstruction. All these analyses were performed using algorithms provided in PAUP v.4.0b10 (Swofford, 2001).

Maximum parsimony (MP) analysis was performed using the heuristic algorithm. To assess the relative support for internal nodes, a bootstrap resampling approach (with 1,000 replicates) was used. Alignment gaps were treated as missing character states for the analyses. Only minimal length trees were kept. Polytomies were permitted. Accelerated transformation was used for character-state optimization. Starting tree obtained via stepwise addition with addition sequence simple, and branch-swapping algorithm by tree-bisection-reconnection.

For distance analysis, neighbor-joining (NJ) trees (Saitou \& Nei, 1987) were generated from Kimura 2-parameter and Kimura 3-parameter (Kimura, 1980) distance matrices. NJ analysis using Kimura distances was performed and statistical support of each $\mathrm{NJ}$ tree was assessed with bootstrap-resampling technique (Felsenstein, 1985) over 1,000 replications. Minimum evolution (ME) analyses were also performed using LogDeterminant (Log-Det) for the estimation of distances (Lockhart et al., 1994), and the corresponding ME trees were generated from the Log-Det corrected distances by NJ analysis. A more complex model, TN93, was also applied to verify whether a better fit of the data could be obtained.

Maximum likelihood (ML) trees were also constructed. To generate a ML tree that best fits the ITS- 2 data, hie- 
rarchical likelihood ratio tests (LRTs) were performed following the procedure outlined in Posada \& Crandall (1998). Depending on the model of DNA evolution employed, parameters such as transition/transversion ratio as well as those associated with the assumption of rate heterogeneity were estimated from actual data (Yang, 1996). The maximum-likelihood values for $\mathrm{ts} / \mathrm{tv}$, gamma shape parameter $\alpha$ and the proportion of invariable sites were estimated separately for the lymnaeid ITS-2 sequences. Empirical base sequencies, where appplicable, were used. Analyses were restricted to five different ML nucleotide substitution models, including HKY85 (Hasegawa et al., 1985), HKY85 $+\Gamma$ (gamma-distributed rates; Yang, 1994b), HKY85 $+\Gamma+\mathrm{I}$ (mixed gamma-distributed rates and invariable sites), GTR (Yang, 1994a), and GTR $+\Gamma+I$ (mixed gamma-distributed rates and invariable sites; $\mathrm{Gu}$ et al., 1995). To provide an assessment of the reliability of the nodes of the trees, a quartet puzzling analysis was employed (with 1,000 puzzling steps); although the quartet puzzling analysis has recently received critics (see Ranwez \& Gascuel, 2001), it is widely used and appropriate here to allow the comparison with previous results obtained on lymnaeids (Bargues et al., 2001).

\section{RESULTS}

\section{SEQUENCE ANALYSES}

1 the rDNA ITS-2 sequences of the two Polish lymnaeids reported in this paper are available in the GenBank/EMBL data bases under the following accession numbers: AJ457042 for L. occulta, and AJ457043 for L. p. turricula. The lengths and GC contents of these ITS-2 sequences were, respectively, $448 \mathrm{bp}$ and $60,7 \%$ for L. occulta, and $473 \mathrm{bp}$ and $58,1 \%$ for L. p. turricola. The 473 bp-long ITS-2 sequence of the $L$. p. palustris topotype from Denmark proved to be identical to that known from other populations of the same nominal subspecies from France, Germany and The Netherlands (AJ319620) (Bargues et al., 2001).

When comparing the ITS-2 sequence of $L$. occulta with those known of other European stagnicoline lymnaeid species, as L. p. palustris (one genotype), L. p. turricula (two genotypes), L. fuscus (four genotypes), and $L$. corvus (one genotype), two differences appear: i) the length in L. occulta ( $448 \mathrm{bp}$ ) is shorter and does not fit into the range shown by European stagnicolines (468-484 bp); ii) the GC content in L. occulta $(60,7 \%)$ is higher and does not enter within the range of the other European stagnicolines (57,9-58,5\%). Surprisingly, both ITS-2 length and GC content of L. occulta are similar and perfectly fit within the respective ranges known in North American stagnicoline lymnaeid species, as $H$. caperata, H. catascopium, H. elodes and H. emarginata (length: $444-449$ bp; GC content: 60,3$60,8 \%)$.

Genetic distances in pairwise comparisons according to Kimura's two-parameter model between different populations of European and American stagnicoline lymnaeid species are shown in Table I. Interestingly, both total and mean character differences are higher between $L$. occulta and the European stagnicolines (108-177 and 0.26601-0.28329, respectively) than between L. occulta and the North American ones (27-76 and 0.06490-0.18095, respectively).

In the different alignments performed between L. occulta and the North American stagnicolines (Table II), ITS-2 sequence differences appear markedly more numerous when compared to $H$. caperata than when compared to the group $H$. emarginata, $H$. elodes and H. catascopium. A total of 103 absolute nucleotide differences $(22.59 \%$ in the respective two-sequence alignment of 456-bp length), including 43 transitions (9.43\%), 30 transversions $(6.58 \%)$ and 30 insertions plus deletions $(6.58 \%)$ were detected between the sequences of $L$. occulta and $H$. caperata, whereas those were only 87-90 absolute nucleotide differences (18,28-18.75\% in two-sequence alignments of $476-481$ bp lengths), including 11-14 transitions (2,29-2.92\%), 14-17 transversions (2,92-3.57\%) and 58-63 insertions plus deletions (12.18-13.10\%) between L. occulta and the group $H$. emarginata, $H$. elodes and $H$. catascopium.

When comparing the ITS-2 sequence of $L$. p. turricula from Poland with those known of other European populations of $L$. p. palustris (one genotype present in Denmark, France, Germany and The Netherlands) and L. p. turricula (two genotypes, both from Salzburg, Austria), very few differences were found. In pairwise sequence alignments (473-bp long), the following differences between $L$. p. turricula from Poland and the above-mentioned genotypes were detected: only one transition $(0.2 \%)$ versus $L$. p. palustris, two transitions plus one transversion $(0.6 \%)$ versus $L$. $p$. turricula GT1, and two transitions plus two transversions $(0.8 \%)$ versus $L$. p. turricula GT2. As the ITS-2 sequence of L. p. turricula from Poland is not equal to any of the previous two genotypes known, it is here designed as genotype 3 (GT3).

In the multiple, 473-bp long ITS-2 sequence alignment including all the three genotypes of $L$. p.turricula plus $L$. p. palustris, only five absolute nucleotide differences were detected $(1.1 \%)$. When the L. fuscus genotypes are included in this alignment, 33 nucleotide differences appear (6.9\% in the 480-bp long alignment), and when $L$. corvus is added to the latter alignment 


\begin{tabular}{|c|c|c|c|c|c|c|c|c|c|c|c|c|c|c|c|}
\hline & 1 & 2 & 3 & 4 & 5 & 6 & 7 & 8 & 9 & 10 & 11 & 12 & 13 & 14 & 15 \\
\hline 1 L. fuscus GT1 & - & 0.00212 & 0.00857 & 0.01285 & 0.03219 & 0.03433 & 0.03004 & 0.02790 & 0.04925 & 0.28266 & 0.28199 & 0.28504 & 0.28297 & 0.27094 & 0.28101 \\
\hline 2 L. fuscus GT2 & 1 & - & 0.00857 & 0.01285 & 0.03219 & 0.03433 & 0.03004 & 0.02790 & 0.04925 & 0.28266 & 0.28199 & 0.28504 & 0.28297 & 0.27094 & 0.28101 \\
\hline 3 L. fuscus GT3 & 4 & 4 & - & 0.00427 & 0.02784 & 0.02998 & 0.02570 & 0.02355 & 0.04915 & 0.28029 & 0.27962 & 0.28504 & 0.28058 & 0.26667 & 0.27848 \\
\hline 4 L. fuscus GT4́ & 6 & 6 & 2 & - & 0.02784 & 0.02998 & 0.02998 & 0.02784 & 0.05342 & 0.27791 & 0.27725 & 0.28266 & 0.27818 & 0.26667 & 0.27848 \\
\hline 5 L.p. turricula GT1 & 15 & 15 & 13 & 13 & - & 0.00634 & 0.00634 & 0.00423 & 0.05085 & 0.28404 & 0.28337 & 0.28873 & 0.28436 & 0.26601 & 0.27273 \\
\hline 6 L.p. turricula GT2 & 16 & 16 & 14 & 14 & 3 & - & 0.00846 & 0.00634 & 0.05297 & 0.28404 & 0.28337 & 0.28873 & 0.28436 & 0.26847 & 0.27525 \\
\hline 7 L.p. turricula $\mathrm{Pol}$ & 14 & 14 & 12 & 14 & 3 & 4 & - & 0.00211 & 0.04873 & 0.28169 & 0.28103 & 0.28638 & 0.28199 & 0.26601 & 0.27020 \\
\hline 8 L.p.palustris & 13 & 13 & 11 & 13 & 2 & 3 & 1 & - & 0.04661 & 0.28404 & 0.28337 & 0.28873 & 0.28436 & 0.26847 & 0.27273 \\
\hline 9 L. corvus & 23 & 23 & 23 & 25 & 24 & 25 & 23 & 22 & - & 0.29792 & 0.29493 & 0.29561 & 0.29604 & 0.28329 & 0.29777 \\
\hline 10 C. emarginata Mi & 119 & 119 & 118 & 117 & 121 & 121 & 120 & 121 & 129 & - & 0.00446 & 0.01116 & 0.01126 & 0.06731 & 0.15633 \\
\hline 11 C. catascopium Wis & 119 & 119 & 118 & 117 & 121 & 121 & 120 & 121 & 128 & 2 & - & 0.00670 & 0.00676 & 0.06490 & 0.15633 \\
\hline 12 C. elodes $\mathrm{Mi}$ & 120 & 120 & 120 & 119 & 123 & 123 & 122 & 123 & 128 & 5 & 3 & - & 0.00676 & 0.06971 & 0.15881 \\
\hline 13 C. catascopium $\mathrm{Mi}$ & 118 & 118 & 117 & 116 & 120 & 120 & 119 & 120 & 127 & & 3 & 3 & - & 0.06971 & 0.15881 \\
\hline 14 C. occulta & 110 & 110 & 108 & 108 & 108 & 109 & 108 & 109 & 117 & 28 & 27 & 29 & 29 & - & 0.18095 \\
\hline 15 H. caperata Man & 111 & 111 & 110 & 110 & 108 & 109 & 107 & 108 & 120 & 63 & 63 & 64 & 64 & 76 & - \\
\hline
\end{tabular}

Below diagonal: total character differences; above diagonal: mean character differences. Pol = Poland; Mi $=$ Michigan, USA; Wis = Wisconsin, USA; Man $=$ Manitoba, Canada.

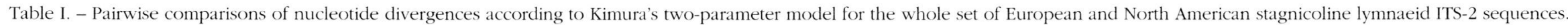

\begin{tabular}{|c|c|c|c|c|c|c|c|c|c|}
\hline \multirow{3}{*}{ Compared species } & \multirow{3}{*}{$\begin{array}{c}\text { Alignment length } \\
\text { Number of bp }\end{array}$} & & & \multicolumn{4}{|c|}{ Substitutions } & \multirow{2}{*}{\multicolumn{2}{|c|}{ Insertions + deletions }} \\
\hline & & \multicolumn{2}{|c|}{ Nucleotide differences } & \multicolumn{2}{|c|}{ Transitions } & \multicolumn{2}{|c|}{ Transversions } & & \\
\hline & & No. & $\%$ & No. & $\%$ & No. & $\%$ & No. & $\%$ \\
\hline C. occulta vs C. emarginata & 480 & 89 & 18.54 & 12 & 2.50 & 15 & 3.12 & 62 & 12.92 \\
\hline C. occulta us C. elodes & 480 & 90 & 18.75 & 14 & 2.92 & 14 & 2.92 & 62 & 12.92 \\
\hline C. occulta us $C$. catascopium $\mathrm{W}$ is & 481 & 90 & 18.71 & 11 & 2.29 & 16 & 3.33 & 63 & 13.10 \\
\hline C. occulta us C. catascopium $\mathrm{Mi}$ & 476 & 87 & 18.28 & 12 & 2.52 & 17 & 3.57 & 58 & 12.18 \\
\hline C. occulta vs $H$. caperata & 456 & 103 & 22.59 & 43 & 9.43 & 30 & 6.58 & 30 & 6.58 \\
\hline
\end{tabular}

Wis $=$ Wisconsin; $\mathrm{Mi}=$ Michigan

Table II. - ITS-2 sequence differences detected in pairwise comparisons between Catascopia occulta and other proximal stagnicoline lymnaeid species. 
differences increase up to 40 ( $8.2 \%$ in the 485 -bp long alignment). If $L$. occulta is included in the multiple alignment of the sequences of the European stagnicolines L. p. palustris, L. p. turricola, L. fuscus and L. corvus, the number of absolute nucleotide differences increases considerably up to $188(35.8 \%)$ in a 525 -bp long ITS2 alignment.

\section{PHYLOGENETIC ANALYSES}

Alignments of the 37 rDNA ITS- 2 sequences representing a total of 68 populations of 14 European and four North American lymnaeid species (and subspecies), including the genus/subgenus taxa Lymnaea, Stagnicola, Omphiscola, Radix, Hinkleyia, and Galba, were used to infer phylogenies.

Because of the inclusion of a species as L. occulta, which appears building a bridge between European and North American lymnaeids, the assay of a especially selected external outgroup appears to be convenient to verify the main branching of the phylogenetic trees, even with the risk of somewhat loosing resolution in small branch differentiation. Thus, for phylogenetic reconstruction, analyses were carried out using three Planorbidae, B. pfeifferi (representing the African Biomphalaria clade), B. amazonica (representing the Neotropical Biomphalaria clade) and H. trivolvis (to include another planorbid genus) (Dejong et al., 2001) as outgroups.

When using the three planorbids as outgroup, a 581position-long alignment was obtained. Of these, 160 sites were constant and 390 were parsimony-informative. All MP, NJ and ML analyses yielded similar trees, where L. occulta did not appear in or linked to the European stagnicoline branch, but clustered together with the North American stagnicoline group.

MP analysis, using the heuristic option, yielded a single most-parsimonious tree (Fig. 1A). The MP tree obtained was 1,002 steps long. $\mathrm{CI}$ and $\mathrm{HI}$ were 0.726 and 0.274 , respectively. RI, RC and G-fit were 0.918, 0.666 and -333.850 , respectively. In distance analysis, very similar topologies and bootstrap values were obtained in the $\mathrm{NJ}$ trees constructed using Kimura 2-parameter (tree not shown) and LogDet distances $($ score $=2.6073)$. TN93 provided a topology identical to that obtained with NJ using LogDet distances, showing slightly higher support values for some branch nodes (Fig. 1B).

For the ITS-2 sequences, the following values were estimated: ts/tv of 1.09 for all lymnaeids and 1.4 for only stagnicolines, $\alpha$ of 0.8 , and the proportion of invariable sites $\mathrm{I}$ of 0.1275 . A ts/tv ratio of 2 was also applied because this ratio had previously shown the best fit for lymnaeid ITS-2 (BARGUES et al., 2001). The ML model best fitting the ITS- 2 data of lymnaeids was HKY 85 using the ts/tv ratio of 2 , in which the log likelihood was 4865.40131, puzzle values obtained were very high (of 100 in all main branches except one with 96) and the number of quartets examined was 91390 using least-squares method with ML distances (Fig. 1C). When $\Gamma$ and I were introduced to HKY85, slightly better - $\ln L$ were obtained, but puzzle values always appeared lower and topologies usually showed incongruent branching results (trees not shown). Using settings corresponding to the GTR model, the likelihood was worse $(-\ln L=4893.1753)$ and the puzzle values were lower in the branches of Radix, American stagnicolines and outgroup planorbids. In GTR $+\Gamma+\mathrm{I}$, the likelihood was better $(-\ln \mathrm{L}=4785.7400)$ but puzzle values were lower than in HKY85 and given branches did not fit appropriately (trees not shown).

All MP, NJ and ML trees showed main branches supported by very high bootstrap and puzzle values (all higher than 90, most of them of 100). The ingroup taxa, representing all lymnaeids studied, are divided into two big clades, one for Radix species and another for all other genera. In this second clade, two branches are well defined: one branch for the European lymnaeids including Lymnaea (Lymnaea), Lymnaea (Stagnicola) and Omphiscola, and another branch comprising the European Galba and L. occulta together with the North American stagnicolines. In the HKY85 tree obtained with ts/tv of 1.09 and without gamma correction and in that obtained with the GTR model, the Omphiscola branch becomes basal to the European stagnicolines, as in the MP and NJ trees, whereas Omphiscola appears only basal to Lymnaea (Lymnaea) in all other trees obtained under the HKY85 model (Fig. 1C).

Summing up, the phylogenetic trees obtained showed similar trees and confirmed $i$ ) the inclusion of $L$. occulta in the branch of $H$. emarginata, $H$. elodes and $H$. catascopium, $i$ ) the link between the North American stagnicolines-L. occulta group with $G$. truncatula, and iii) the location of L. p. turricula GT3 from Poland closer to L. p. palustris than to L. p. turricula GT1 and GT2.

\section{DISCUSSION}

\section{LYMNAEA OCCULTA AND HOLARCTIC STAGNICOLINES}

The lengths of the lymnaeid ITS-2 vary within a very large range. Three different lymnaeid species groupings according to their ITS-2 length could be distinguished (Bargues et al., 2001): Radix and Galba may be considered the oldest taxa (370-406 bp lengths), and Lymnaea s. str., European Stagnicola and Omphiscola (468-491 bp lengths) the most recent, North American stagnicolines being intermediate (434-450 bp lengths). This hypothesis agrees with the phylogeny of lymnaeids based on palaeontological data, chromosome numbers and radular dentition (Inaba, 1969). That is why the sequence results obtained on L. occulta 

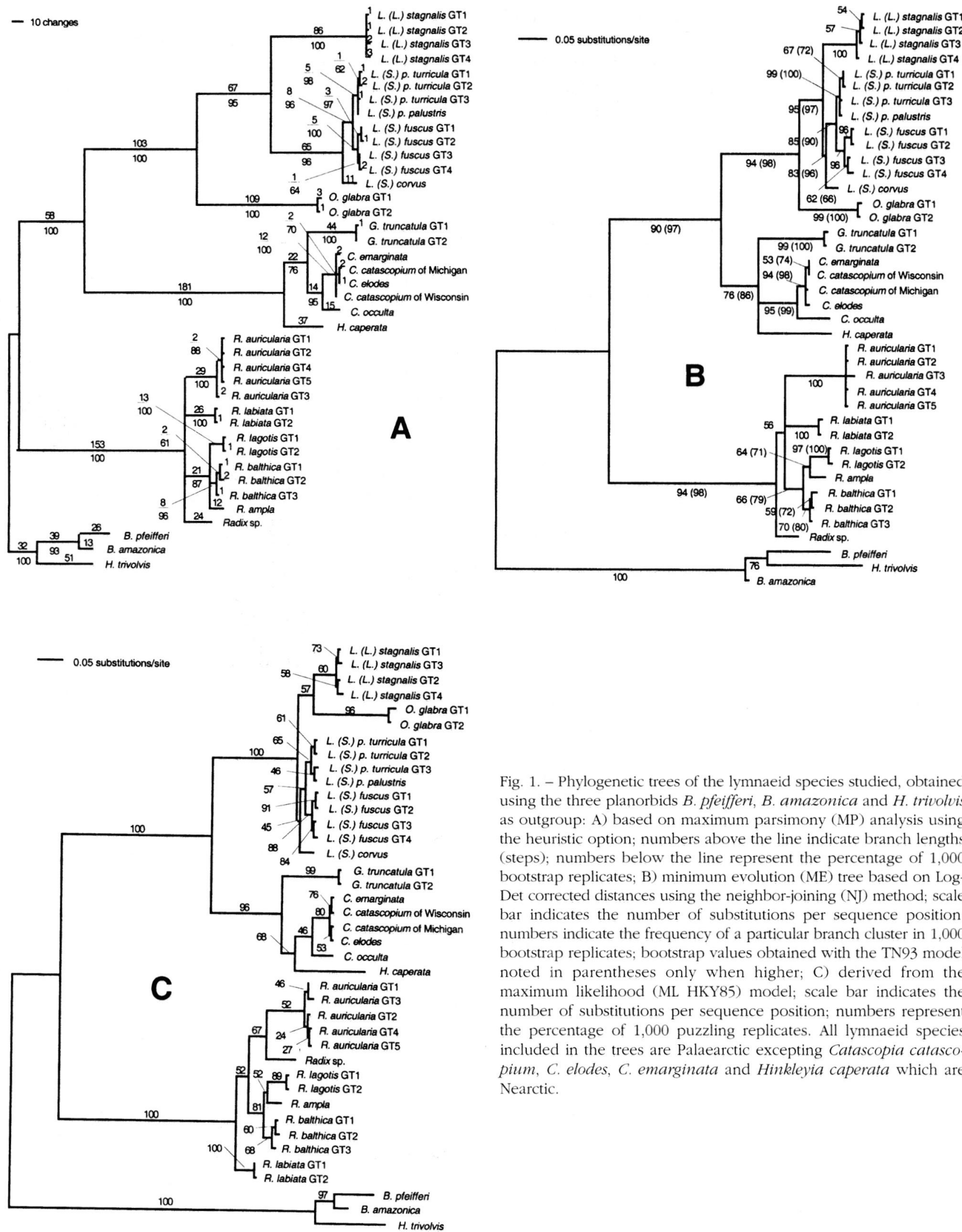

Fig. 1. - Phylogenetic trees of the lymnaeid species studied, obtained using the three planorbids $B$. pfeifferi, B. amazonica and $H$. trivolvis as outgroup: A) based on maximum parsimony (MP) analysis using the heuristic option; numbers above the line indicate branch lengths (steps); numbers below the line represent the percentage of 1,000 bootstrap replicates; B) minimum evolution (ME) tree based on LogDet corrected distances using the neighbor-ioining (NJ) method; scale bar indicates the number of substitutions per sequence position; numbers indicate the frequency of a particular branch cluster in 1,000 bootstrap replicates; bootstrap values obtained with the TN93 model noted in parentheses only when higher; C) derived from the maximum likelihood (ML HKY85) model; scale bar indicates the number of substitutions per sequence position; numbers represent the percentage of 1,000 puzzling replicates. All lymnaeid species included in the trees are Palaearctic excepting Catascopia catascopium, C. elodes, C. emarginata and Hinkleyia caperata which are Nearctic 
are so interesting: both ITS- 2 length and its GC content fit in the ranges of the American stagnicolines. Moreover, MP, NJ and ML analyses are all furnishing phylogenetic trees in which $L$. occulta is always clustering with the American stagnicolines.

In all phylogenetic analyses performed previously, European stagnicolines always appeared in a clade different from that of North American ones. These phylogenetic results, together with the great nucleotide differences and genetic distances, suggested that North American and European stagnicolines do not belong to the same supraspecific taxon, despite shell morphology and visceral anatomy similarities which may be homoplasic (Bargues et al., 2001). Similar conclusions were reached in trees inferred from $16 \mathrm{~S}$ mitochondrial rDNA sequences (Remigio \& Blair, 1997a; Remigio, 2002).

The results obtained in the present work suggest that L. occulta may be considered an evolutionary bridge between Palaearctic and Nearctic stagnicolines. In this sense, it is worth mentioning that $L$. occulta shows a geographical distribution in Europe restricted to eastern and northern regions, as eastern Germany (Glöer \& Meier-Brook, 1998), Poland, former Czechoslovakia, former Yugoslavia, Ukraine and Sweden (Jackiewicz, 1998a). Moreover, it has been found in Jenisejsk and the Selenga river delta at the Baikal Lake, Siberia (Jackiewicz, 1992, 1998b), and its high resistance to dryness and water freezing (Jackiewicz, 1998a) suggest that it may be largely expanded up to the Asian Far East where it may have been confused with other stagnicoline species because of its shell morphology. Stagnicoline materials, originally ascribed to different species and later put together within the taxon L. palustris sensu lato by Hubendick (1951), have been reported up to the Peninsula of Kamchatka, in Alaska, Canada, USA and central Mexico, and even introduced into Panama (see review by Hubendick, 1951). The future sequencing of these American stagnicolines may largely clarify our present knowledge on this interesting Holarctic lymnaeid group.

The species L. occulta presents a well known morphoanatomy which includes a singular combination of features of the reproductive organs (see review in Jackiewicz, 1998a). Although the results obtained with the random amplified polymorphic DNA (RAPD) technique should be taken into account with a great caution in taxonomical studies (Backeljau et al., 1995), RAPD studies were already suggesting the separate taxonomic status of L. occulta, electrophoretic band analyses being unable to clarify its taxonomic position in Stagnicola or Lymnaea s. str. (Rybska et al., 2000).

Absolute differences in the rDNA ITS- 2 sequences and the genetic distances between L. occulta and the other stagnicoline species do not only prove the validity of this species, but also show that it cannot be included in the European subgenera Lymnaea (Lymnaea) Lamarck, 1799 (type species: stagnalis) and Lymnaea (Stagnicola) (Jeffreys, 1830) (= Stagnicola Leach, 1830; = Limnophysa Fitzinger, 1833) (type species: palustris), nor in the closest North American genus Hinkleyia Baker, 1928 (type species: caperata), nor in the neighbouring European genus Galba Schrank, 1803 (type species: truncatula). The genetic distances detected between $L$. occulta and H. caperata $(0.18095)$ or between L. occulta and G. truncatula (0.15426-0.15691) are higher-similar than those detected between the genera Omphiscola and Lymnaea (Lymnaea) or Lymnaea (Stagnicola) (0.15217-0.17577) (see Bargues et al., 2001).

The inclusion of the L. occulta evolutionary bridge in the phylogenetic trees has largely contributed to clarify the status of the different Holarctic stagnicolines. Ribosomal DNA ITS-2 sequence analyses and phylogenetic results now agree with the conclusion reached by Remigio \& Blair (1997b) after the study of the ITS$1,5.8 \mathrm{~S}$ and ITS-2 nuclear rDNA sequences about the convenience of ascribing catascopium-elodes-emarginata and caperata to two different genera. Moreover, present results suggest that L. occulta and the American catascopium, emarginata and elodes belong to the same supraspecific taxon, genetic distances between them being very low (0.06490-0.06731).

Consequently, the nomination of a new genus Catascopia with catascopium as type species and also including the species emarginata, elodes and occulta, has been proposed (Meier-Brook \& Bargues, 2002).

\section{LYMNAEA PALUSTRIS SUBSPECIES}

The results in the rDNA ITS- 2 sequence analyses and respective phylogenetic trees confirm the previous results on L. palustris and L. turricula obtained by Bargues et al. (2001). All ITS-2 sequences from lymnaeids, classified as belonging to these two species, studied up to the present, correspond to the same species and, consequently, molecular results suggest that L. turricula must be considered conspecific with L . palustris. RAPD distances and electrophoretic bands were already suggesting that both were very close (Rybska et al., 2000).

If the morpho-anatomic differences in the reproductive organs, as the ratio of the praeputium to the penis sheath length and prostate shapes, especially in the length ratio of its proximal part to the distal one (see Jackiewicz, 1998a), would show a relationship to populations showing different geographical/ecological distributions, their distinction at subspecies level, L. $p$. palustris and L. p. turricula, would be possible.

The present knowledge gives L. turricula a distribution comprising the Danube valley in Germany, southern Poland, Czech Republic, Austria, Hungary, and Bulgaria (Falkner, 1984, 1985; Jackiewicz, 1989, 1996, 1998a; 
Kilias, 1992; Glöer \& Meier-Brook, 1998; Rybska et al., 2000). This distribution includes overlapping areas, which does not necessarily mean coexistence of both palustris and turricula in the same localities.

Worth mentioning is that all $L$. p. palustris populations studied up to the present, even from localities very far away ones from the others (Denmark, France, Germany, The Netherlands), showed identical ITS-2 sequence. Such a monomorphic phenomenon is unique among European lymnaeids, as in all other species from which more than one population could be studied, an intraspecific variability in the ITS-2 sequence was found (Bargues et al., 2001). Thus, in this case, one wonders whether the presence of only a very few mutations, as those detected in the different $L$. p. turricula populations studied, would be sufficient to correlate with the phenotypic differences at the base of their species/subspecies distinction. The sequencing of additional nuclear ribosomal and mitochondrial DNA markers evolving faster than the ITS-2 is here needed.

\section{STAGNICOLINE VECTORS OF THE LIVER FLUKE}

Fascioliasis is an important disease in humans and livestock caused by two digenetic trematode species of the genus Fasciola: F. hepatica and F. gigantica. Whereas in Europe, the Americas and Oceania only F. hepatica is concerned, the distributions of both species overlap in many areas of Africa and Asia (Mas-Coma \& Bargues, 1997; Mas-Coma et al., 1999). Fasciola hepatica is believed to be of European origin, with Galba truncatula as the original intermediate host species (MasComa et al., 2001). F. gigantica appears to be restricted to areas of Africa and Asia where Radix species are present, mainly forms of $R$. auricularia in Asia and of R. natalensis in Africa. Radix is not present in the New World, the only species of this genus known in North America, $R$. auricularia and $R$. peregra, having been introduced from Eurasia (Hubendick, 1951; Clarke, 1981). Although parasitological data support an origin of Fasciola in the Old World, probably Palaearctic, hypotheses suggest an evolutionary origin for lymnaeids in the Nearctic region, where this group of freshwater gastropods shows its greatest number of species (Hubendick, 1951).

The marked Fasciola/lymnaeid species specificity suggests an old parasite/host relationship of $F$. hepatica with Galba and of F. gigantica with Radix. The monophyletisms shown by both Galba and Radix in the phylogenetic trees of the European lymnaeids are in agreement with known Fasciola/lymnaeid species relationships and suggest a parallel evolution of each liver fluke species with both different lymnaeid branches towards an increasing specificity (Bargues et al., 2001). The phylogenetic trees obtained from the ITS-2 sequences are consequently able to differentiate between lymnaeids transmitting and those non-transmitting fasciolids, as well as between those transmitting $F$. hepatica and those transmitting $F$. gigantica, similarly as trees inferred from $18 \mathrm{~S}$ rDNA sequences did (Bargues \& Mas-Coma, 1997; Bargues et al., 1997).

There are lymnaeid species belonging to taxa other than Galba able to play the role of intermediate host of $F$. hepatica in given circumstances. In Europe, F. hepatica has the lymnaeid G. truncatula as the preferred transmitting snail species. However, O. glabra, L. (S.) palustris and recently $R$. ovata have also been found transmitting it under natural conditions (Kendall, 1970; Bouix-Busson \& Rondelaud, 1985, 1986; Dreyfuss et al., 1994, 2002). Moreover, experimental studies have shown that O. glabra, L. (S.) palustris and L. (S.) fuscus, and even L. (L.) stagnalis, R. peregra and Myxas glutinosa (Müller, 1774) can be extremely infected if miracidium infection takes place during the first few days of the snail's life, although a high mortality level is the consequence (Kendall, 1970; Boray, 1978; Brown, 1978; Vareille-Morel et al., 1994; Dreyfuss et al., 2000, 2002).

In North America, among the numerous lymnaeids incriminated in the transmission of $F$. hepatica, several belong to the stagnicoline group too: L. palustris from Southwestern USA could be experimentally infected (Wilson \& Samson, 1971), although the same species could not be infected in Wisconsin (Foreyt, 1978); L. palustris nutaliana Lea, 1841 was found to be the most important vector, both naturally and experimentally, and L. proxima proxima Lea, 1856 to be an additional natural and experimental intermediate host, both in Washington (Lang, 1977); L. traskii Tryon, 1863 and L. montanensis Baker, 1913 could both only be experimentally infected when very young (Krull, 1934; Rowan et al., 1966). These lymnaeids were all synonymised with L. palustris by Hubendick (1951) and L. montanensis appears to be very close to Hinkleyia caperata, a species which could not be experimentally infected in Wisconsin (Foreyt, 1978).

According to its close relationship to $L$. (S.) p. palustris and position in the phylogenetic trees obtained, the stagnicoline $L$. (S.) p. turricula may be considered as a potential secondary intermediate host of $F$. hepatica. As in the case of $L$. (S.) p. palustris, a natural infection with $F$. hepatica has already been reported in a population of this lymnaeid in Poland (Czapski, 1977), where the main vector species $G$. truncatula is also present (Jackiewicz, 1998a).

Results of DNA sequences and phylogenetic trees suggest a potential of transmission capacity for C. occulta higher than that of European stagnicolines or O. glabra. The relatively low genetic distances between C. occulta and $G$. truncatula and the clustering of both species in the same clade suggest that $C$. occulta may be poten- 
tially considered as the second lymnaeid intermediate host species of $F$. hepatica in importance in eastern and northern Europe after $G$. truncatula. Unfortunately, no conclusion can be drawn from the only known report of a natural infection of $C$. occulta with the liver fluke in Poland (Czapski, 1962). Both experimental transmission studies in the laboratory and epidemiological research in fascioliasis endemic areas, where C. occulta is present, are needed to know whether this lymnaeid species only plays the role of intermediate host sporadically or may be considered a lymnaeid developing an important role in the transmission. This question will attain high interest, owing to the large distribution of this species in eastern Europe and Asia.

\section{ACKNOWLEDGEMENTS}

S tudy supported by Projects No. BOS2002-01978 and No. BOS2000-0570-C02-02 of the DGICYT of the Spanish Ministry of Science and Technology, Madrid, by the Red de Investigación de Centros de Enfermedades Tropicales - RICET (Project No. C03/04 of the Programme of Redes Temáticas de Investigación Cooperativa) of the Fondo de Investigación Sanitaria, Spanish Ministry of Health, Madrid, by the Project No. $89.93 / 1,058$ of the Plan Tecnológico (Programa 2: Promoción de la $I+D$ Precompetitiva) of the Instituto de la Mediana y Pequeña Industria de la Generalitat Valenciana (IMPIVA), Valencia, and by Czech Ministry of Education Grant. No. J13/981131-4, Prague.

Materials of L. p. palustris topotypes and information on lymnaeid systematics and nomenclature furnished by $G$. Falkner (Germany) are greatly acknowledged. Dr. David Swofford generously provided the beta test version of PAUP $4.0 \mathrm{~b} 6$ to M.D. Bargues. Technical support for the authomatic sequencing of lymnaeids was provided by the DNA Sequencing Service of the University of Valencia (A. Martínez and M.T. Cornet).

\section{REFERENCES}

Almeyda-Artigas R.J., Bargues M.D. \& Mas-Coma S. ITS-2 rDNA sequencing of Gnatbostoma species (Nematoda) and elucidation of the species causing human gnathostomiasis in the Americas. Journal of Parasitology, 2000, 86, 537544 .

Backeljau T., De Bruyn L., De Wolf H., Jordaens K., Van Dongen S., Vehagen R. \& WInnepenninckx B. Random amplified polymorphic DNA (RAPD) and parsimony methods. Cladistics, 1995, 11, 119-130.

Bargues M.D. \& Mas-Coma S. Phylogenetic analysis of lymnaeid snails based on 185 rDNA sequences. Molecular Bio$\log y$ and Evolution, 1997, 14, 569-577.
Bargues M.D., Mangold A.J., Muñoz-Antoli C., Pointier J.P. \& MAS-COMA S. SSU rDNA characterization of lymnaeid snails transmitting human fascioliasis in South and Central America. Journal of Parasitology, 1997, 83, 1086-1092.

Bargues M.D., Vigo M., Horak P., Dvorak J., Patzner R.A., Pointier J.P., Jackiewicz M., Meier-Brook C. \& Mas-Coma S. European Lymnaeidae (Mollusca: Gastropoda), intermediate hosts of trematodiases, based on nuclear ribosomal DNA ITS-2 sequences. Infection, Genetics and Evolution, 2001, 1, 85-107.

BORAY J.C. The potential impact of exotic Lymnaea spp. on fascioliasis in Australia. Veterinary Parasitology, 1978, 4, 127-141.

BoutX-Busson D. \& Rondelaud D. Étude de l'aptitude à l'infestation fasciolienne chez Lymnaea glabra Müller et chez L. truncatula dans des peuplements mono- et bispécifiques. Bulletin de la Société Française de Parasitologie, 1985, 33, 95-98.

BoutX-Busson D. \& Rondelaud D. L'infestation de Lymnaea glabra Müller par Fasciola hepatica L. Étude expérimentale sur le terrain. Annales de Parasitologie Humaine et Comparée, 1986, 61, 215-225.

Brown D.S. Pulmonate molluscs as intermediate hosts for digenetic trematodes. In: Pulmonates, Vol. 2A. Systematics, Evolution and Ecology. Fretter V. \& Peake J. (eds), Academic Press, London, 1978, 287-333.

Burch J.B. Erinna newcombi of Hawaii and Limnaea onychia of Japan. Malacological Review, 1968, 1, 15-30.

Burch J.B. \& Lindsay G.K. Apparent hybrids from a laboratory culture of Lymnaea stagnalis and Bulimnea megasoma. Malacological Review, 1973, 6, 61-62.

Clarke A.C. The freshwater molluscs of Canada. National Museums of Canada, Ottawa, 1981.

CZAPSKI Z. The snail Galba occulta Jackiewicz, 1959, another intermediate host of Fasciola hepatica L. Zeitschrift für Tropenmedizin und Parasitologie, 1962, 13, 332-337.

CZApski Z. Biologiczne aspekty epidemiologii fasciolozy. Monografie, Podreczniki, Skrpty AWF w Poznaniu, 1977, 95, 1-143.

De Jong R.J., Morgan J.A.T., Paraense W.L. et al. Evolutionary relationships and biogeography of Biomphalaria (Gastropoda: Planorbidae) with implications regarding its role as host of the human bloodfluke, Schistosoma mansoni. Molecular Biology and Evolution, 2001, 18, 22252239.

Dreyfuss G., Moukrim A., Rondelaud D. \& Vareille-Morel C. Field observations concerning infection of Lymnaea palustris by Fasciola hepatica. Journal of Helminthology, 1994, $68,115-118$.

Dreyfuss G., Abrous M. \& Rondelaud D. The susceptibility of Lymnaea fuscus to experimental infection with Fasciola bepatica. Journal of Parasitology, 2000, 86, 158-160.

Dreyfuss G., Vignoles P., Abrous M. \& Rondelaud D. Unusual snail species involved in the transmission of Fasciola bepatica in watercress beds in central France. Parasite, 2002, 9, 113-120.

Erasmus D.A. The Biology of Trematodes. Edward Arnold (Publ.), London, 1972, $312 \mathrm{pp}$. 
FALKNeR G. Stagnicola palustris (O.F. Müller) vom Originalfundort (Basommatophora: Lymnaeidae). Heldia, München, 1984, 1, 15-21.

FALKNer G. Stagnicola turricula (Held), eine selbstständige Art neben Stagnicola palustris (O.F. Müller). Heldia, München, 1985, 1, 47-50.

Falkner G., Ripken T.E.J. \& Falkner M. Mollusques continentaux de France. Liste de référence annotée et bibliographie. Patrimoines Naturels (Muséum National d'Histoire Naturelle de Paris), 2002, 52, 1-350.

Felsenstein J. Confidence limits on phylogenies: an approach using the bootstrap. Evolution, 1985, 39, 783-791.

FOREYT W.J. Experimental infection of lymnaeid snails in Wisconsin with miracidia of Fascioloides magna and Fasciola bepatica. Journal of Parasitology, 1978, 64, 1132-1134.

Glöer P. \& MeIER-Brook C. Süsswassermollusken. Ein Bestimmungsschlüssel für die Bundesrepublik Deutschland, 12th edn. Deutscher Jugendbund für Naturbeobachtung, Hamburg, 1998, 136 pp.

GU X., FU Y.X. \& LI W.H. Maximum likelihood estimation of the heterogeneity of substitution rate among nucleotide sites. Molecular Biology and Evolution, 1995, 12, 546-557.

Hasegawa M., Kishino H. \& Yano T. Dating of the humanape split by a molecular clock by mitochondrial DNA. Journal of Molecular Evolution, 1985, 22, 160-174.

Hubendick B. Recent Lymnaeidae. Their variation, morphology, taxonomy, nomenclature, and distribution. Kungliga Svenska Vetenskapsakademiens Handlingar, Fjärde Serien, 1951, 3 (1), 1-223 (+ $5 \mathrm{pl})$.

InABA A. Cytotaxonomic studies of lymnaeid snails. Malacologia, 1969, 7, 143-168.

JACKIEWICZ M. Galba turricula Held sensu Jackiewicz, 1959 als jüngers Synonym von Stagnicola palustris (O.F. Müll.) (Gastropoda, Basommatophora: Lymnaeidae). Malakologische Abhandlungen des Museums für Tierkunde in Dresden, 1989, 14, 1-5.

JACKIEWICZ M. Lymnaea (Stagnicola) occulta (Jackiewicz 1959) (Gastropoda: Pulmonata) in Sibirien. Mitteilungen der Deutschen Malakozoologischen Gesellschaft, Frankfurt am Main, 1992, 49, 13-16.

JACKIEWICZ M. Concerning Hungarian populations of "Galba palustris" studied by Kilias (1992) (Gastropoda: Pulmonata: Lymnaeidae). Malakologische Abhandlungen des Museums für Tierkunde in Dresden, 1996, 18, 165-172.

JACKIEWICZ M. European species of the family Lymnaeidae (Gastropoda: Pulmonata: Basommatophora). Genus, 1998a, 9, $1-93$

JACKIEWICZ M. Lymnaea (Stagnicola) occulta (Jackiewicz, 1959) in the Selenga River delta at the Baikal Lake (Siberia) (Gastropoda: Basommatophora: Lymnaeidae). Malakologische Abhandlungen des Staatliches Museum fur Tierkunde Dresden, 1998b, 19, 53-57.

Kendall S.B. Relationships between the species of Fasciola and their molluscan hosts. Advances in Parasitology, 1970, 9, 251-258.

Kilias R. Vergleichend-anatomische Untersuchungen an "Galba palustris (O.F. Müller)" von ungarischen Fundorten als Beitrag zur palustris-Problematik (Gastropoda, Basom- matophora: Lymnaeidae). Malakologische Abhandlungen, 1992, 16, 25-29.

Kimura M. A simple method for estimating evolutionary rates of base substitutions through comparative studies of nucleotide sequences. Journal of Molecular Evolution, 1980, 16, 111-120.

KRULL W.H. The intermediate hosts of Fasciola bepatica and Fascioloides magna in the United States. North American Veterinarian, 1934, 15, 13-17.

LAKE J.A. The order of sequence alignment can bias the selection of tree topology. Molecular Biology and Evolution, 1991, 8, 378-385

LANG B.Z. Snail and mammalian hosts for Fasciola bepatica in Eastern Washington. Journal of Parasitology, 1977, 63, 938-939.

Lockhart P.J., Steel M.A., Hendy M.D. \& Penny D. Recovering evolutionary trees under a more realistic model of sequence evolution. Molecular Biology and Evolution, 1994, 11, 605-612.

Mas-Coma S. \& Bargues M.D. Human liver flukes: a review. Research and Reviews in Parasitology, 1997, 57, 145-218.

Mas-Coma S., Bargues M.D. \& Esteban J.G. Human Fasciolosis. In: Fasciolosis. Dalton J.P. (ed.), CAB International Publishing, Wallingford, Oxon, UK, 1999, 411-434.

Mas-Coma S., Funatsu I.R. \& Bargues M.D. Fasciola bepatica and lymnaeid snails occurring at very high altitude in South America. Parasitology, 2001, 123, S115-S127.

Mas-Coma S., Bargues M.D., Valero M.A. \& Fuentes M.V. Adaptation capacities of Fasciola bepatica and their relationships with human fascioliasis: from below sea level up to the very high altitude. In: Taxonomy, Ecology and Evolution of Metazoan Parasites Combes C. \& Jourdane J. (eds), University of Perpignan Press, Perpignan, 2003, 2, 81-123.

Meier-Brook C. \& Bargues M.D. Catascopia, a new genus for three Nearctic and one Palaearctic stagnicoline species (Gastropoda: Lymnaeidae). Folia Malacologica, Poznan, 2002, 10, 83-84.

Oviedo I.A., Bargues M.D. \& Mas-Coma S. Lymnaeid snails in the human fascioliasis high endemic zone of the Northern Bolivian Altiplano. Research and Reviews in Parasitology, 1995, 55, 35-43.

Posada D. \& CRANDall K.A. Modeltest: testing the model of DNA substitution. Bioinformatics, 1998, 14, 817-818.

RANwEZ V. \& Gascuel O. Quartet-based phylogenetic inference: improvements and limits. Molecular Biology and Evolution, 2001,18, 1103-1116.

Remigio E.A. Molecular phylogenetic relationships in the aquatic snail genus Lymnaea, the intermediate host of the causative agent of fascioliasis: insights from broader taxon sampling. Parasitology Research, 2002, 88, 687-696.

Remigio E.A. \& Blair D. Molecular systematics of the freshwater snail family Lymnaeidae (Pulmonata: Basommatophora) utilising mitochondrial ribosomal DNA sequences. Journal of Molluscan Studies, 1997a, 63, 173-185.

Remigio E.A. \& Blair D. Relationships among problematic North American stagnicoline snails (Pulmonata: Lymnaeidae) reinvestigated using nuclear ribosomal DNA internal 
transcribed spacer sequences. Canadian Journal of Zoo$\log y, 1997 \mathrm{~b}, 75,1540-1545$.

Rowan W.B., Lehmkuhl B. \& Russell R.H. Stagnicola (Hinkleyia) montanensis (Baker, 1913), a new experimental snail host for Fasciola hepatica. Journal of Parasitology, 1966, $52,247$.

Rybska E., Pacak A., Szweykowska-Kulinska Z. \& Lesicki A. Taxonomy of European Lymnaeidae (Gastropoda: Pulmonata) in studies with the use of molecular biology techniques. I. Preliminary view on the subgenus Stagnicola Leach, 1830 on the basis of RAPD analysis. Folia Malacologica, Poznan, 2000, 8, 277-284.

SAITOU N. \& NeI M. The neighbor-joining method: a new method for reconstructing phylogenetic trees. Molecular Biology and Evolution, 1987, 4, 406-425.

Samadi S., Roumegoux A., Bargues M.D., Mas-Coma S., Yong M. \& Pointier J.P. Morphological studies of lymnaeid snails from the human fascioliasis endemic zone of Bolivia. Journal of Molluscan Studies, 2000, 66, 31-44.

SAmbroOK J., Fritsch E.F. \& Maniatis T. Molecular Cloning. A Laboratory Manual. 2nd edn. Cold Spring Harbor Laboratory Press, New York, 1989, Vols. I, II \& III, 1647 pp.

SANGer F., NiCKLEN S. \& Coulson A.R. DNA sequencing with chain-terminating inhibitors. Proceedings of the National Academy of Sciences of the USA, 1977, 74, 5463-5467.

SWOFFORD D.L. PAUP*: phylogenetic analysis using parsimony (*and other Methods). Version 4. Computer program distributed by the Smithsonian Institution, Sinauer Associates, Inc. publishers, Sunderland, Massachusetts, 2001.

Thompson J.D., Higgins D.G. \& Gibson T.J. ClustalW: improving the sensitivity and progressive multiple sequence alignment through sequence weighting, positions-specific gap penalties and weight matrix choice. Nucleic Acids Research, 1994, 22, 4673-4680.

Vareille-Morel C., Rondelaud D. \& Dreyfuss G. L'infestation expérimentale de Myxas glutinosa Müller par le trématode Fasciola bepatica Linné. À propos de quelques observations histologiques. Bulletin de la Société Française de Parasitologie, 1994, 12, 35-42.

WALTER H.J. Illustrated biomorphology of the "angulata" lake form of the Basommatophoran snail Lymnaea catascopium Say. Malacological Review, 1969, 2, 1-102.

WILSON G.I. \& SAMSON K.S. The incidence of fascioliasis of sheep and cattle in the Southwest with observations on the snail vectors. Proceedings of the Helminthological Society of Washington, 1971, 38, 52-56.

YANG Z. Estimating the pattern of nucleotide substitution. Journal of Molecular Evolution, 1994a, 39, 105-111.

YANG Z. Maximum likelihood phylogenetic estimation from DNA sequences with variable rates over sites: approximate methods. Journal of Molecular Evolution, 1994b, 39, 306314.

YANG Z. Among-site rate variation and its impact on phylogenetic analysis. Trends in Ecology and Evolution, 1996, $11,367-372$.

Reçu le 16 octobre 2002 Accepté le 13 juin 2003 